\title{
Ambient Vibration Response of Precast Hollow Core Flooring System
}

\author{
Rahimi M.I., Abd Ghafar N.H., Mohd Jaini Z., Ibrahim Z.
}

\begin{abstract}
Prestressed precast hollow core is known as a long span slab with a void along its length. The void has a big influence on the weight of the slab. In vibration theory, a lightweight slab with a long span is very sensitive to vibration. In this study, the ambient vibration response of precast hollow core is investigated using the finite element method and modal analysis. Numerical analysis is used to predict the floor vibration and modal testing is used to test the vibration performance of floors on the actual site. The prediction data is obtained by using SAP2000 to determine the vibration behaviour and compared with the modal testing result of the floor located in Kuala Lumpur. The 1st mode shape appeared for 12 natural frequencies between $8.36 \mathrm{~Hz}$ to $9.29 \mathrm{~Hz}$ in the prediction analysis. For modal testing, the vibration behaviour of the actual hollow core floor is determined using an ambient test. The data was obtained using an accelerometer and analysed using Artermis software to determine natural frequencies, damping ratio and mode shape. The 1st mode of natural frequencies for floor area $A$ and area $B$ were $8.45 \mathrm{~Hz}$ and $9.34 \mathrm{~Hz}$. The results from the analysis show that the range of natural frequency between the predicted analysis and that of the modal testing is acceptable. The limitation stated that $10 \mathrm{~Hz}$ is the cut-off frequency to determine the class of the floor. From the analysis, it is shown that the prediction and the modal testing results are accepted where both floors are classified as low-frequency floors.
\end{abstract}

Keywords: hollow core floor, vibration, modal testing, ambient vibration, prediction analysis, floor serviceability, low frequency floor

\section{INTRODUCTION}

The source of vibration can be defined from human activity and external force where loads or forces are applied directly to the floor (Svinkin, 2004; Pretti et al., 2014).

Revised Manuscript Received on February 14, 2020.

* Correspondence Author

Muhammad Imran Rahimi, Graduate Research Assistant, Department of Structural \& Material Engineering, Universiti Tun Hussein Onn Malaysia, 86400 Batu Pahat, Malaysia. Email: muhdimranrahimi@yahoo.com

Nor Hayati Abd Ghafar*, Senior Researcherr, Department of Civil Engineering, Faculty of Civil Engineering \& Buil Environment, Universiti Tun Hussein Onn Malaysia, 86400 Batu Pahat, Malaysia. Email: noryati@uthm.edu.my

Zainorizuan Mohd Jaini, Researcherr, Department of Civil Engineering, Faculty of Civil Engineering \& Buil Environment, Universiti Tun Hussein Onn Malaysia, 86400 Batu Pahat, Malaysia. Email: rizuan@uthm.edu.my

Zainah Ibrahim, Associate Professor, Department of Civil Engineering, Faculty of Engineering, University of Malaya, 50603 Kuala Lumpur, Malaysia. Email: zainah@um.edu.my

(C) The Authors. Published by Blue Eyes Intelligence Engineering and Sciences Publication (BEIESP). This is an open access article under the CC BY-NC-ND license (http://creativecommons.org/licenses/by-nc-nd/4.0/)

Human activities such as walking, jumping and dancing cause vibration. Other common sources of vibration come from the environment and mechanical equipment which cause excessive floor vibration. Conducting ambient tests on hollow core floors can help determine its vibration behaviour during low amplitude vibration. Low amplitude vibration is caused by natural sources of vibration surrounding the structure (Ivanovic et al. 2000: Wenzel and Pichler,2005: Kim et al., 2019). Natural sources include seismic phenomena, wind and waves. Highly sensitive acceleration is used to measure the linear vibration of floors as the amplitude is too small. In this study, the hollow core floor design with a longitudinal void along its length is classified as lightweight concrete. The properties and advantages of hollow core slabs lie in its weight (Monisha and Srinivasan, 2017). Economically, the hollow makes the floor much lighter than existing reinforced solid floors with equal thickness or strength. Furthermore, hollow core slabs are much more flexible compared to other types of concrete slabs. However, its long span and low weight can cause excessive floor vibration. Excessive vibrations are linked to floor properties, where lightweight concrete material is more likely to receive excitation compared to heavyweight concrete.

The response of the vibration based on acceleration reading of floors from the Frequency Response Function (FRF) measurement is given by amplitude versus time. The excitation FRF is transformed by Fourier Transform (FT) from the time domain function to the frequency domain function (Asher, 2013). The accelerations are converted to determine the natural frequency of the floor. Natural frequency is the number of cycles of motion when structure is set in motion or when a structure is disturbed from its static equilibrium position and oscillated (Ellis and Ji, 1994; Johansson, 2009). The peak excitation response is the reading that states the natural frequency of the floor that shows the behaviour or condition of the structure that has an impact on human comfort. There is a limit, also known as a cut-off frequency, depending on the material in construction. The cut-off frequency has been set by different authors and design guidelines. It is based on different materials, floor type and usage of the floors. General floors as open office space areas with concrete material floor are limited to a cut-off frequency of $10 \mathrm{~Hz}$ based on SCI P345 (Smith et al ,2009). The cut-off frequency of SCI P354 agrees with that set by the concrete society and the concrete centre (Pavic and Willford ,2005: Willford and Young,2006). Each of the limits has a different frequency in order to set a limit between low-frequency floors and high-frequency floors. 


\section{Ambient Vibration Response of Precast Hollow Core Flooring System}

Low-frequency is a response dominated by a resonant build-up while high-frequency is a response due to successive footfall (Mohammed, 2018). Human comfort is affected by low-frequency floors where vibrations can be felt through the floor. High-frequency floors are better for human comfort and serviceability. The aims of this study are to predict the vibration behaviour of pre-stressed precast hollow core floors using finite element modeling and to determine the vibration behaviour of pre-stressed precast hollow core floors through modal testing.

\section{STRUCTURAL DETAILING}

Four-storey office buildings were constructed using steel I-beam and concrete beams for some parts of the structure. Grade C30/37 concrete was used for in-situ floors and zero slump C50 concrete was used for hollow core precast floor with a $350 \mathrm{~mm}$ thick shear wall. The building consists of open space areas and a concrete wall partition in the middle area of the floor. The building includes a workstation area, a meeting room, a filing room and welfare facilities.

The floors of the building were constructed using two types of floors: in-situ concrete slabs for the middle part of the office area and precast hollow core slabs for the rest of the floors as shown in Fig. 1. However, only precast hollow core slabs were examined and analysed in this study. The precast hollow core width was $1200 \mathrm{~mm}$ with a span of $8 \mathrm{~m}$ and installed with a $75 \mathrm{~mm}$ concrete topping. The depth of the precast hollow core slab is $265 \mathrm{~mm}$ and the cross section of the hollow core is illustrated in Fig. 2.

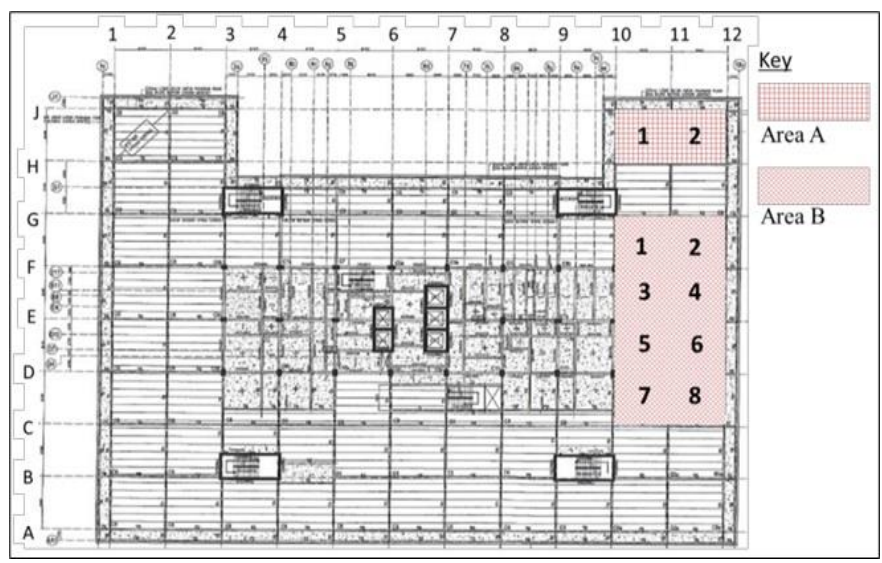

Fig. 1 Office building floor layout

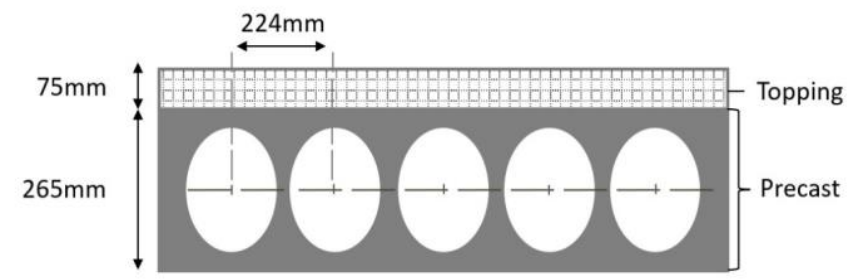

Fig. 2 Hollow core slab cross section

\section{PREDICTION ANALYSIS}

The floor was modelled using SAP 2000 finite element software package to predict the vibration behaviours before conducting the experimental work. The floor was assigned shell elements and analysed using the modal analysis method. The shell elements consisted of 6 degrees (U1, U2, U3, R1, R2 and R3) of freedom at each node. The modelling consisted of shell and frame elements for beams, columns and slabs. The shell element was used for slabs and frame elements were used for beams and columns as shown in Fig. 3. As for prediction analysis, pinned restraints were applied at every point of the column. The first twelve natural frequencies were determined between $8.36 \mathrm{~Hz}$ to $9.29 \mathrm{~Hz}$ as illustrated in Fig. 4. The natural frequencies were below $10 \mathrm{~Hz}$ as recommended by Zivanovic and Pavic (2009) for precast flooring systems. This level of frequency is exposed to an excitation resonance that causes annoyance to humans. Fig. 4 shows the first mode shape from the FEM results. It shows only some parts of the floor on mode 1,4 and 5 which are critical and on both cantilever floor areas on mode shape 2, 3, 6 and 7. The first mode shape appeared at a large area of the floor at mode 8 to 12. Fig. 1 shows the critical area gridlines from the prediction analysis for testing. Based on the FEM prediction analysis, Floor A (H-J/10-12) consisting of 2 bays and Floor B (C-G/1-12) consisting of 8 bays were selected to conduct modal testing. Only two floors were chosen due to time constraints and the available area of the floor. The floor and the building were still under construction, thus some of the areas cannot be accessed.

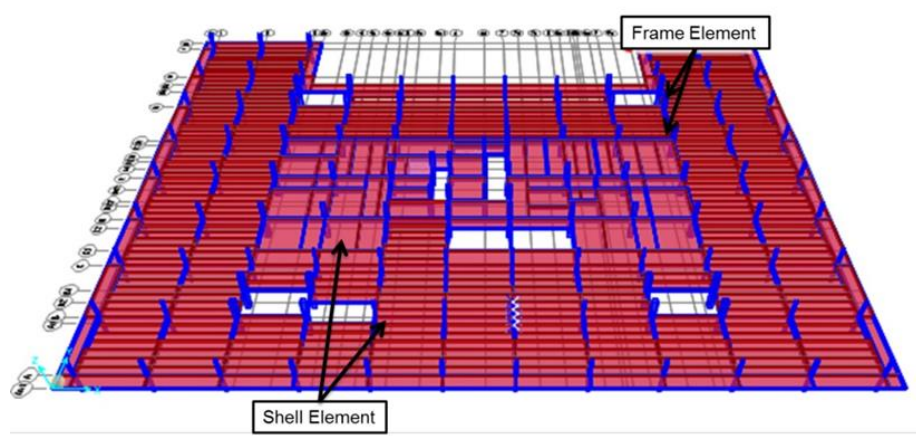

Fig. 3 Model elements in SAP2000

\section{AMBIENT VIBRATION RESPONSE}

The ambient test was conducted at the test location to determine the natural frequency, damping ratio and mode shape without any force on the hollow core slab. The data was collected by accelerometers at each point. Accelerometers were attached to the floor to record floor response as shown in Fig. 5. The duration of testing for each set was 10 minutes. 7 sets of tests were performed for floor area A and 11 set of tests were performed for floor area B. The total number of roving accelerometers used in the test was 16 . 3 points were stated as reference points and the accelerometers were set up as shown in Fig. 5. The data was analysed using the Artemis software to determine the natural frequency, damping ratio and mode shape. The raw data was transformed to FT and the modal estimation was based on Frequency Domain Decomposition (FDD) to determine the natural frequency damping ratio and mode shape. The vibration behaviour was determined using the peak pick-ing method as shown in Fig. 6. Floor A consisted of 7 sets of data for 2 bays. As shown in Fig. 7(a), the mode shape globally deformed at the 1st and 2nd mode on both bays. At 3rd mode, it begins to deform locally at some parts and the maximum deformation appeared mostly at bay 2 . For the 4th to 6 th mode, the critical areas were deformed locally at both bays. 


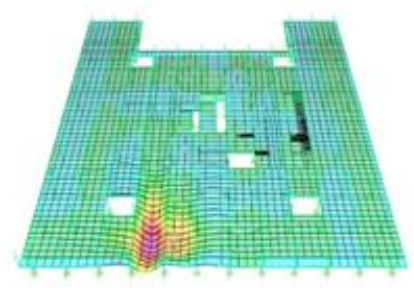

(a) Mode $1\left(\mathrm{f}_{\mathrm{n}}: 8.36 \mathrm{~Hz}\right)$

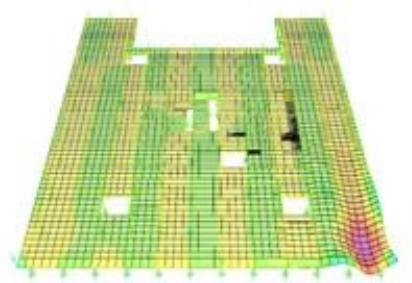

(d) Mode $4\left(f_{n}: 8.69 H z\right)$

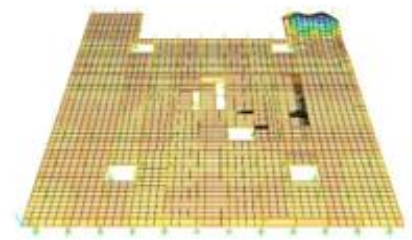

(g)Mode $7\left(f_{n}: 8.79 H z\right)$

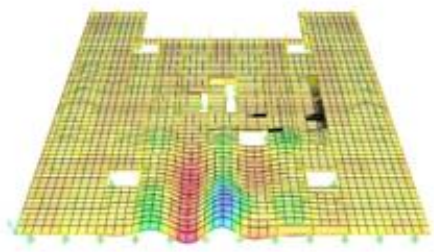

(j) Mode $10\left(f_{n}: 9.11 \mathrm{~Hz}\right)$

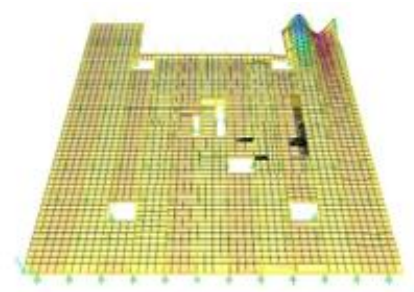

(b) Mode $2\left(f_{n}: 8.58 \mathrm{~Hz}\right)$

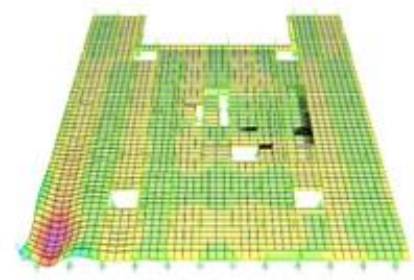

(e) Mode $5\left(f_{n}: 8.70 \mathrm{~Hz}\right)$

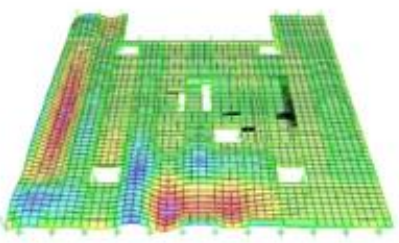

(h) Mode $8\left(f_{n}: 9.05 \mathrm{~Hz}\right)$

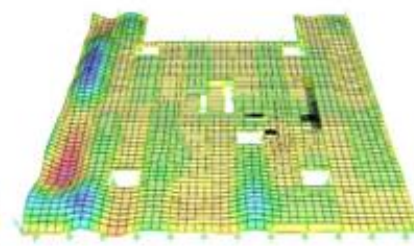

(k)Mode $11\left(f_{n}: 9.28 \mathrm{~Hz}\right)$

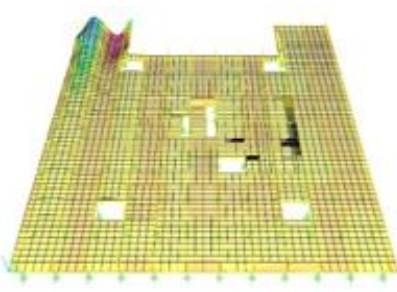

(c) Mode $3\left(f_{n}: 8.61 \mathrm{~Hz}\right)$

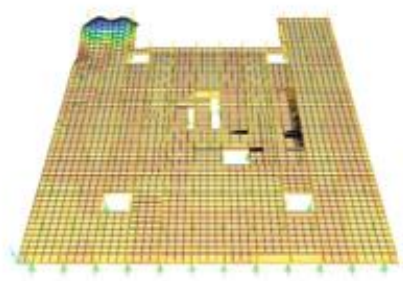

(f) Mode $6\left(f_{n}: 8.79 H z\right)$

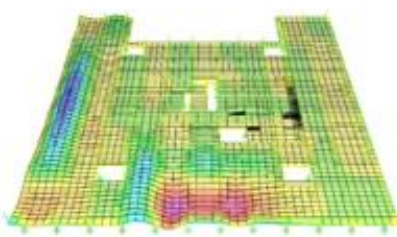

(i) Mode $9\left(f_{n}: 9.06 \mathrm{~Hz}\right)$

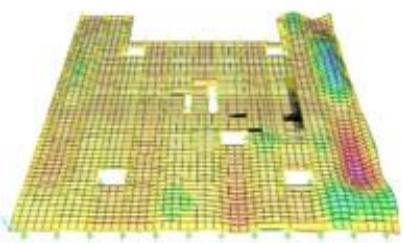

(1) Mode $12\left(f_{n}: 9.29 \mathrm{~Hz}\right)$

Fig. 4 Prediction Response

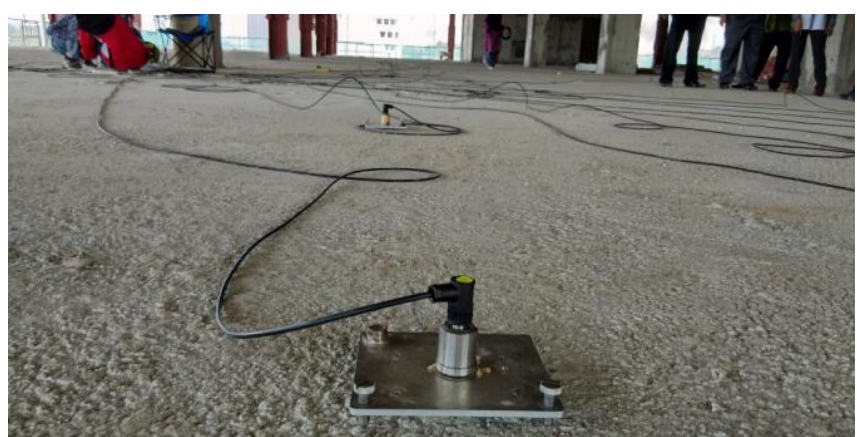

Fig. 5 Accelerometer setups at floor area A. $\mathrm{f}_{\mathrm{n}}: 14.80 \mathrm{~Hz}$

$\zeta: 0.68 \%$

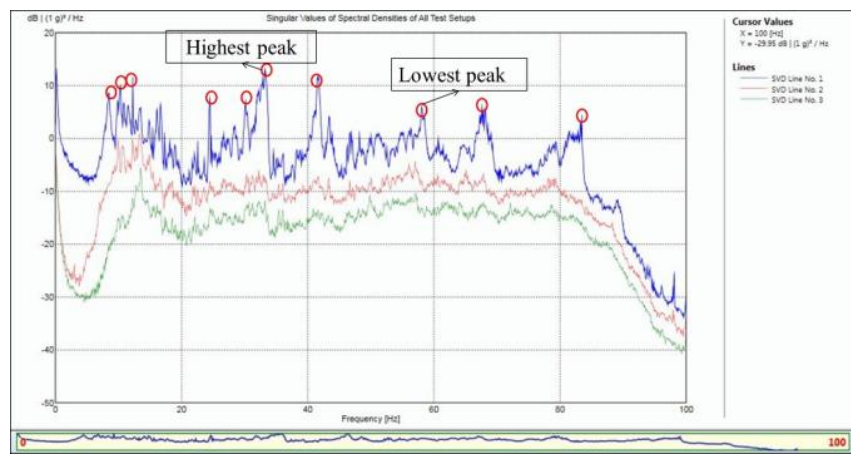

Fig. 6 Peak picking method in Artemis software.

The local deformed shape showed that the deformation occurred on the precast it-self. Floor B consisted of 11 sets of data for 8 bays. As shown in Fig. 7(b), the behaviour of mode shape is different in large areas.

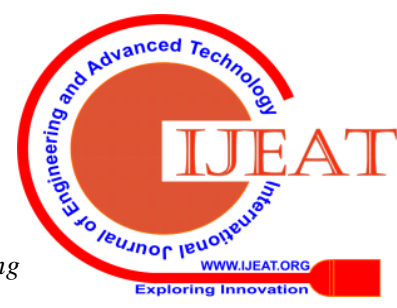




\section{Ambient Vibration Response of Precast Hollow Core Flooring System}

For the 1st and 2nd mode, the deformation appeared on all bays where the maximum deformation occurred at bay 6 to 8 . At the 3rd to 6th mode, deformation appeared locally at some parts of the bay. This mode is considered a rare shape as it was probably influenced by noise. The maximum deformation within the mode mostly occurred at bay 7 and 8 .

The influence of noise and outsource vibration may lead to rare mode shapes and affect the damping ratio. Based on the results, the damping percentages decreased from $4.04 \%$ to $0.4 \%$ and $4.21 \%$ to $0.24 \%$ for floor area A and floor area B, respectively. This result shows that the higher the frequency, the lower the percentage of the damping ratio. A low damping ratio leads to frequent floor vibration.

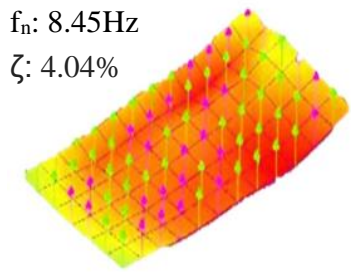

(a). Mode 1

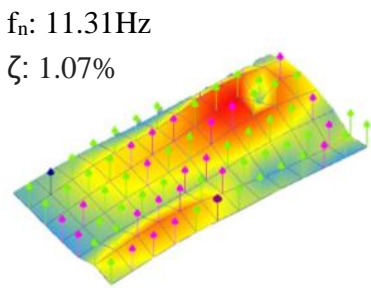

(c). Mode 3

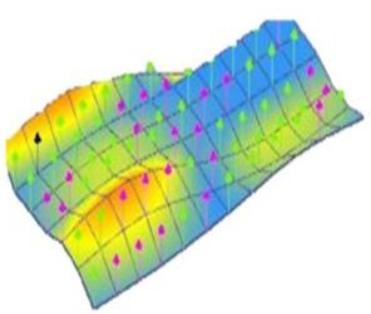

(e). Mode 5

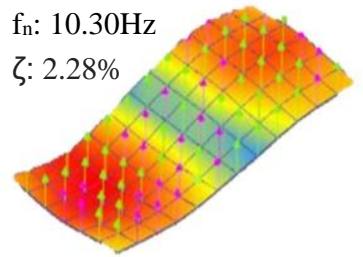

(b). Mode 2

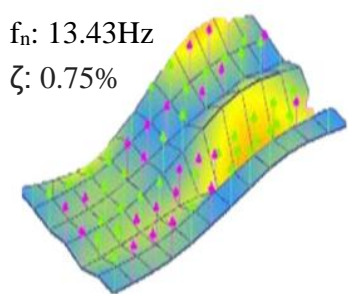

(d). Mode 4

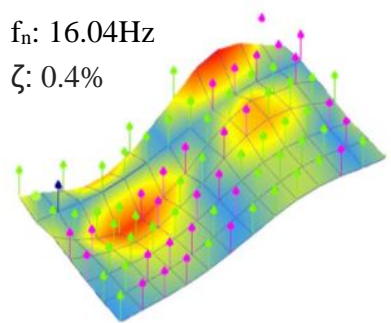

(f). Mode 6

Fig. 7(a) Vibration behaviour of floor area A (H-J/10-12)

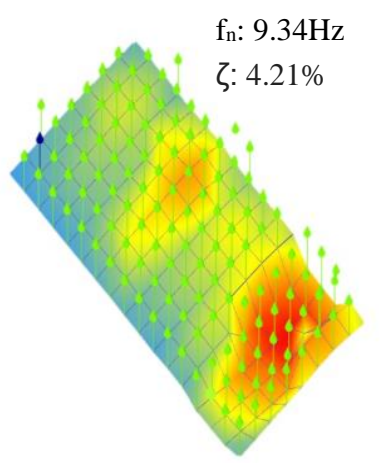

(a). Mode 1

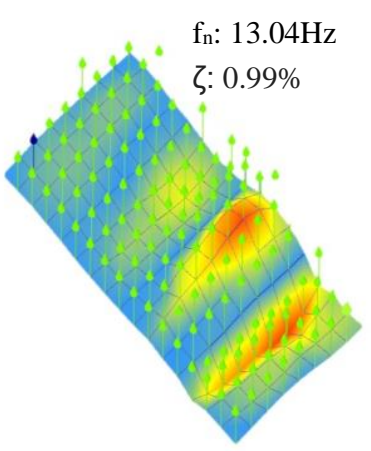

(b). Mode 2

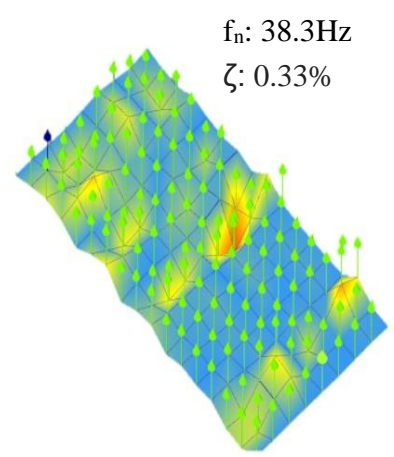

(c). Mode 3

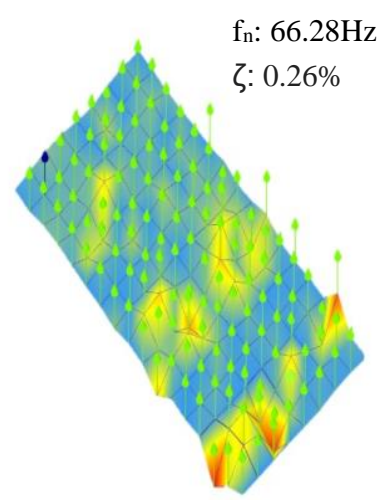

(e). Mode 5

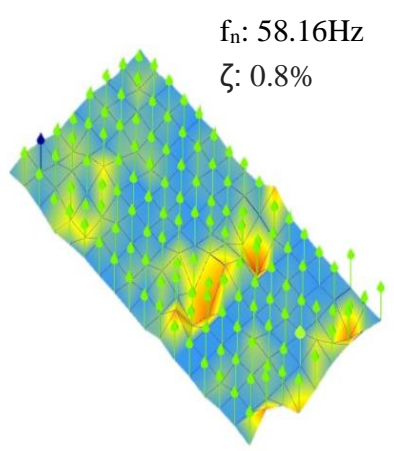

(d). Mode 4

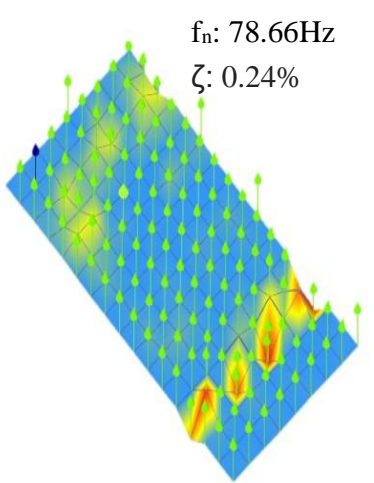

(f). Mode 6
Fig. 7(b) Vibration behaviour of floor area $B$ (C-G/1-12)

\section{DISCUSSION}

According to the FEM results for the prediction analysis and the ambient test, the analysis was considered reasonable due to the same range of frequency in the 1st mode. In prediction, the result came out with a reading of $8.36 \mathrm{~Hz}-9.29 \mathrm{~Hz}$ and for the modal testing, the results obtained the same frequency range where the frequency of floor area $\mathrm{A}$ was $8.45 \mathrm{~Hz}$ while the frequency of floor area B was $9.34 \mathrm{~Hz}$. According to the concrete society (Willford et al.,2006), $10 \mathrm{~Hz}$ is the cut-off between low-frequency floors and high-frequency floors. Results from both analyses show that the frequency obtained was below $10 \mathrm{~Hz}$, so the floor can be classified as a low-frequency floor. Several assumptions can be used to explain the low-frequency floor in this study. The precast hollow core slab can be considered a lightweight concrete due to its long span and lightweight properties. In addition, the hollow core slab has more flexibility compared to other types of concrete slabs. For this research, the length for each span is $8 \mathrm{~m}$ long and the hollow contributes to the low mass. Due to its long span and light weight, precast hollow core slab is more flexible and sensitive to vibration compared to heavy slabs. In addition, the boundary of the hollow core slabs in the study freely rested on the beam. The hollow core itself was not attached to the beam.

The measured FRF and mode shape behaviour are affected by a certain level of noise due as the modal testing was conducted during construction day. The floor area resided in open spaces and the floor was not completely empty as people were moving around.

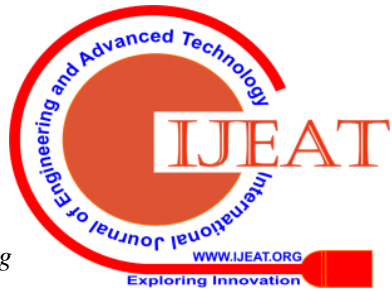


These factors along with its properties and boundary condition have possibly contributed to the vibration behaviour of hollow core slabs in this study.

\section{CONCLUSION}

The aim of the study was to predict the critical area of vibration behaviour in a building by using FEM and to determine vibration behaviour through modal testing on critical areas. This research presents the FEM, modal testing and modal analysis approach to determine the vibration behaviour of a precast hollow core flooring system. In order to determine the prediction results, an FEM software named SAP2000 was used in the numerical analysis using frame, beam and shell elements. The predicted results were used as a guide to conduct a test to measure floor vibration. The test conducted on site was an ambient test which measured floor vibration using roving accelerometers. The results for both analyses were acceptable as the predict-ed result had the same range of frequency as that of the modal testing. As the floor is classified as a low-frequency floor area, the serviceability of the floor is weak. Through all the analyses, it can be concluded that the objective to determine vibration behaviour through prediction analysis and modal testing of the hollow core flooring system has been achieved.

\section{ACKNOWLEDGMENT}

This research has been supported by the internal grant "Geran Penyelidikan Pascasiswazah" (GPPS) (No: H389) by the Research Management Centre, Centre for Graduate Studies and the Faculty of Civil and Environmental Engineering (FKAAS) of Universiti Tun Hussein Onn Malaysia.

\section{REFERENCES}

1. Asher, K. (2013). Fourier series and fourier transform. IOSR Journal of Mathematics, 4(6), 2278-5728.

2. Ivanovic, S., Trifunac, M., \& Todorovska, M. (2000). Ambient vibration tests of structures-a review. ISET Journal of Earthquake Technology, 37(4), 165-197.

3. Johansson, P. (2009). Vibration of Hollow Core Concrete Elements Induced by Walking. Master Thesis. Lund Institute of Technology, Sweden.

4. Kim, C. W., Kawabe, D., \& Kondo, M. (2019). Ambient vibration monitoring of a railway bridge for scour detection. Proceedings of IABMAS 2018, 923-928. Melbourne, Australia.

5. Liu B. (2001). Transducers for Sound and Vibration - The Finite Element Method Based De-sign. PhD Thesis. Technical University of Denmark, Denmark.

6. Mohammed, A. S., Pavic, A., \& Racic, V. (2018). Improved model for human induced vibrations of high-frequency floors. Engineering Structures, Vol.168. 950-966. DOI: 10.1016/j.engstruct.2018.04.093

7. Monisha, K. M., \& Srinivasan, G. (2017). Experimental Behaviour of Prestress Hollow Core Slab, Rc Hollow Core Slab and Normal Rc Solid Slab. International Journal of Engineering and Technical Research (IJETR), Vol. 4(4), 1090-1093.

8. Pavic A, Willford MR. (2005) Vibration serviceability of post-tensioned concrete floors - CSTR43 App G. Appendix G in post-tensioned concrete floors design handbook - technical report 43 2005:99-107

9. Pretti, L. A., Ferreira, W. G., \& Calenzani, A. F. G. (2014). Vibrations due to walking and aerobics activities: a theoretical verification. Ibracon Structures and Materials Journal, 7(2), 286-312. DOI: 10.1590/S1983-41952014000200006

10. Smith, A. L., Hicks, S. J., \& Devine, P. J. (2009). Design of Floors for Vibration: New Approach (Revised Ed). Berkshire: The Steel Construction Institute.

11. Svinkin M.R (2004). Minimizing construction vibration effects, Practice
Periodical on Structural Design and Construction, ASCE, Vol.9(2), pp 108 - 115. DOI: 10.1061/(ASCE) 1084-0680(2004)9:2(108

12. Wenzel, H., \& Pichler, D. (2005). Ambient Vibration (Vol. 5). The Atrium, Southern Gate, Chichester, West Sussex PO19 8SQ, England: John Wiley \& Sons Ltd.

13. Willford, M. R., \& Young, P. (2006). A Design Guide for Footfall Induced Vibration of Structures. United Kingdom: The Concrete Centre.

14. Živanović, S., \& Pavić, A. (2009). Probabilistic modeling of walking excitation for building floors. Journal of performance of constructed facilities, Vol.23(3), DOI:10.1061/(ASCE)CF.1943.5509.0000005

\section{AUTHORS PROFILE}

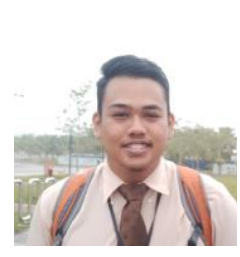

Muhammad Imran Rahimi, an M.Eng student at Universiti Tun Hussein Onn Malaysia in the Department of Civil Engineering. His research interest focuses on the vibration behavior of the floor system in modal analysis and finite element analysis.

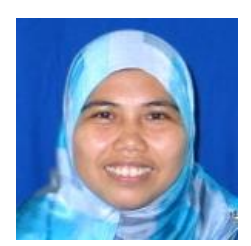

Nor Hayati Abd Ghafar, is a senior lecturer at Universiti Tun Hussein Onn Malaysia in the Department of Civil Engineering. She obtained her Ph.D. in Civil Engineering from the University of Canterbury, New Zealand, in 2016. Her research interest focuses on dynamic engineering, floor vibration, and green technology.

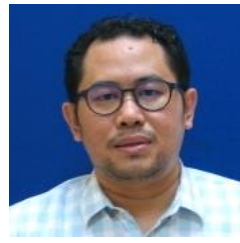

Zainorizuan Mohd Jaini, is a lecturer at Universiti Tun Hussein Onn Malaysia in the Department of Civil Engineering. He obtained his Ph.D. in Civil Engineering from Swansea University, the United Kingdom, in 2003. His research interest focuses on computational multi-scale modelling, hybrid finite-discrete element method, structural damage and progressive collapse and vibration.

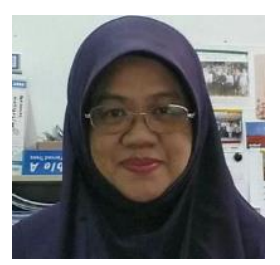

Zainah Ibrahim, is currently an Associate Professor at the Department of Civil Engineering, University of Malaya, Kuala Lumpur, Malaysia She obtained her Ph.D. in the field of Structural Engineering from Sheffield University, UK, in 2006. Her research interest focuses on structural dynamics, structural health monitoring, nonlinear dynamic system identification, structural vibration and control, repair and strengthening of existing concrete structures, and concrete materials. 